\title{
0157 DISABILITY ADJUSTED LIFE YEARS (DALYS) DUE TO OCCUPATIONAL INJURIES IN EAST DELTA REGION OF
} EGYPT

W S Eldin*, J M Hirshon, G S Smith, A M Kamal, A Abou-El-Fetouh, M El-Setouhy Correspondence: Faculty of Medicine, AinShams University, 52-Ali Amin Street, Nasr City, Cairo, 11371, Egypt

\subsection{6/ip.2010.029215.157}

Background Occupational injuries are a public health problem. Determining rates, types and burden of occupational injuries is critical in planning prevention strategies.

Objectives To describe the epidemiology of occupational injuries in the Eastern Delta industrial region of Egypt and to measure the burden of these injuries in terms of DALYs.

Method A retrospective chart review was conducted of all individuals with occupational injuries presenting in 2008 to the Nile Insurance Hospital, the main East Delta Hospital for insured patients.

Results During 2008, there were 2129 occupational injuries presenting to the Nile Insurance Hospital. Cases were 85\% males with mean age 30.79 years (range 1859 years). Ninetyfive percent of injuries reportedly occurred inside the workplace, with the most frequent cause $(40 \%)$ contributed to collision against machines or part of a machine. About $89 \%$ of injuries occurred during work; $4.7 \%$ of cases occurred going to or from work. Previous work injuries were report by $41 \%$ of injured workers. Hands/fingers were the most frequently affected body part. Among different industries present in the East Delta region, the glass/crystal industry had the highest incidence rate of injuries (112.6/1000 workers). Crystal polishing workers were the most frequently injured workers (36.5\%). Only 3.1\% of injuries resulted in partial disability. The overall reported injuries resulted in 367.53 DALYs.

Conclusions This study identifies potential high risk industries and occupations in the East Delta region of Egypt. Preventive measures should be targeted against such factors. 